\title{
Uroš Mozetič
}

University of Ljubljana

Faculty of Arts, English Department

\section{The Rack-Brain Pencil-Push of hurt-in-hiding: Translating the Poetry of Seamus Heaney into Slovene}

\author{
Summary
}

The paper raises the issue of the Slovene possibilities of translating culture-, politics-, and language-specific poetic texts of the Irish author Seamus Heaney. The inquiry has been triggered by the unfavourable response to the poet's work in Slovenia, which is all the more telling in light of other modern Irish writers, especially dramatists, who have lately gained firm ground and acquired sympathy from the Slovene public. Our comparison of Heaney's poems with their Slovene translations is, therefore, aimed at elucidating the main reasons for such a tepid response, drawing mainly on a variety of the Slovene stylistic, linguistic, and pragmatic interpretations of his poetic output, which happen to be more often than not at variance with the author's intrinsic poetic output and thus the chief culprit in the misapprehension of his poetic communiqué.

Key words: Seamus Heaney, translation strategies and norms, political and social discourse, intercultural rapport

\section{Bob ob steno birokrata tuge-v-tajnosti: prevajanje poezije Seamusa Heaneyja v slovenščino}

Povzetek

Članek obravnava možnosti prevodnega posredovanja specifičnih kulturnih, političnih in jezikovnih posebnosti poetike irskega avtorja Seamusa Heaneyja, ki je, za razliko od večine Nobelovih lavreatov in zlasti irskih dramatikov naletel v Sloveniji na mlačen odziv. V pričujoči razpravi skušamo osvetliti in pojasniti razloge za takšen sprejem, in sicer na jezikovni, slogovni in pragmatični ravnini. Ugotavljamo, da je bila poetična misel Seamusa Heaneyja v slovenskem prostoru v večini primerov neprimerno ali celo napačno posredovana, ker se slovenski prevajalci niso primerno lotili avtorjeve posebne rabe diskurza, ki vključuje tako sinhrone kot diahrone jeziko(slo)vne prakse.

Ključne besede: Seamus Heaney, prevodne strategije in norme, politični in družbeni diskurz, medkulturno razmerje 


\section{The Rack-Brain Pencil-Push of hurt-in-hiding: Translating the Poetry of Seamus Heaney into Slovene}

\section{Introduction}

What prompted me to compose this paper springs from several occasions or circumstances. The first one is a reflection of my reading of the existing Slovene translations of Seamus Heaney's poems and the observations of the many inadequacies of these translations. The second reason is my first-hand experience with Heaney in that I have spent the past years trying to render into Slovene these profoundly Irish-universal poems, particularly those from his latest poetry collection, Electric Light (2001). Furthermore, there are other circumstances regarding the position of Seamus Heaney in Slovenia, which are perhaps even more thought-provoking in the post-artistic sense. Curiously enough, Heaney has been the least discussed and translated English-writing Nobel laureate author in Slovenia. In fact, it was not until 1995 that he attracted some critical and translation interest, when he received the Nobel Prize for literature. The Slovene translators' reserved attitude towards Heaney's poetry may be, at least to some extent, understandable, the reasons for which, I hope, will become obvious in my analysis of his poetic language and style; the Slovene critics' disinterestedness in Seamus Heaney, however, is hardly explicable, given the frequently-drawn social, political, and psychological parallels between the Irish and the Slovene such as their history of struggle for national identity and the preservation of the mother tongue under the "oppressor's wrong", as well as the sporadically hinted-at common human mentality, largely reflected in the national Irish-Slovene (cf. Böll 1957 and Trstenjak 1992) inclination towards symptoms such as melancholy, guilt, lack of selfconsciousness and fatalism, not to mention their share in alcohol-inspired macabre humour. All these traits have led the two nations along fairly convergent lines of political and humanist emancipation; therefore I believe that the cultivation and promotion of the bond between the Slovene and Irish literary traditions should be placed to the forefront of a joint pursuit.

My itinerary through the Slovene receptionist history of Seamus Heaney sets out on an interesting paradox. The contemporary Slovene literary critics and poets, while invariably crediting W. B. Yeats with being one of the most influential Irish poets ever within the Slovene literary frame, somewhat inadvertently overlook Seamus Heaney's worldwide-recognised succession to the Irish poetic throne. It is true that one has to always allow for the possibility of critical inclusion-exclusion treatment based on criteria and preferences other than the author's general acclaim, but the fact is that Heaney's relation to the tradition of Irish literature has never really become a point of debate among the Slovene-Irish-English literary critics. I have sought for reasons, but to no avail. Seamus Heaney remains a Slovene enigma of its own. Therefore, the only way of coming closer to this Irish Sphinx, "the shape with lion body and the head of a man", is to look at some of the Heaney translations into Slovene. The answer to the riddle may reside, as in times antique, in the sculptor-translator who "well those passions read", thanks to his self-appointed accreditation to the unique proximity of the original. 
Seamus Heaney has repeatedly admitted his indebtedness to W. B. Yeats. Apparently, what he most admires about Yeats and what he is determined to "wring from the acorn" is Yeats' ability to 'remake himself' by rewriting or by turning to a completely new subject and treatment. And this is precisely what makes Heaney such an intriguing poet, especially from a translator's point of view. Even though Heaney has kept certain recognisable poetic procedures ever since the publication of his first collection, Death of a Naturalist, in 1966, he has also demonstrated a persistent inclination towards change in language, style and subject matter.

\section{Plough-child (Death of a Naturalist)}

With Death of a Naturalist, Heaney introduced himself as a poet "of rural Irish origins, writing of matters deeply rooted in Irish experience" (O'Donoghue 1994, 35) with an unquenching thirst for his ancestral sod and a directness articulated through a sharp eye for its particulars. The central features in this collection, as they bear on language and which every translator should bear in mind, are first a primitivism of subject and object; second, "there is a striking recurrence", as observed by Bernard O'Donoghue, "of a contrast between hard and soft materials and surfaces which the language used reflects ..., a contrast between hard, consonantal English and soft, vocalic Irish ..." (ibid., 47). This seems to be perfectly in tune with the poet's popular phrases "phonetics and feeling", and "phonetic fantasy" - "the inextricability of sound and meaning" (ibid., 129). And third, there is Heaney's immaculate verbal representation of manual labour, with a meticulous sense of the smallest detail down to the last grain of wheat. Heaney, admittedly, is like a farmer who will never say: "From here to that tree over there", but rather, "from here to that hornbeam, copper beach, birch...". I propose, on this score, to take a look at a central poem from this collection, 'Follower', and juxtapose it with two separate Slovene translations. I have highlighted a few constitutive and/or translation-wise problematic expressions and phrases.

\section{Follower}

My father worked with a horse-plough, His shoulders globed like a full sail strung Between the shafts and the furrow. The horses strained at his clicking tongue.

An expert. He would set the wing And fit the bright steel-pointed sock. The sod rolled over without breaking. At the headrig, with a single pluck

Of reins, the sweating team turned round And back into the land. His eye Narrowed and angled at the ground, Mapping the furrow exactly.

\section{Naslednik}

Moj oče je obdeloval prst s plugom,

$\mathrm{Z}$ rameni, ki bila so kakor jadra

Napeta vmes med brazdo in ojesi.

Konja sta se napela, ko je tlesknil

Z jezikom. Strokovnjak. Naravnal je boke

In svetli lemež z jekleno ostjo.

Prst se je obračala, ne da bi se

Zdrobila. In zadoščal je trzljaj headrig: left out

Uzd, da se je pôtni team obrnil

In zaoral nazaj. Njegovo oko

Se je zožilo in premerilo zemljišče,

Da bi začrtalo natančno brazdo. 
I stumbled in his hobnailed wake,

Fell sometimes on the polished sod; Sometimes he rode me on his back

Dipping and rising to his plod.

I wanted to grow up and plough,

To close one eye, stiffen my arm.

All I ever did was follow

In his broad shadow round the farm.

I was a nuisance, tripping, falling,

Yapping always. But today

It is my father who keeps stumbling

Behind me, and will not go away.
Jaz pa sem se opotekal v njegovi

Močnó izruti brazdi, in včasih padel;

Včasih pa jahal na njegovem hrbtu,

Ki se je spuščal in dvigal med delom.

Želel sem si odrasti in orati,

Zatisniti oko, napeti mišice.

Vse, kar sem kdaj naredil, je bilo,

Da sem sledil njegovi senci po kmetiji.

Bil sem nadloga, ki nenehoma

Skaklja in pada in blebeče. Danes

Pa je moj oče tisti, ki se opoteka

Tik za menoj, in noče, noče proč.

\section{Translated by}

Boris A. Novak and Irena Zorko Novak

\section{Naslednik}

Moj oče je oral s konjsko vprego,

Njegova pleča so se izbočila kot polno jadro

Med ročicami in brazdami.

Konja sta se napela, ko je tlesknil z jezikom.

Mojster. Pognal je wing: left out

In jekleni lemež je zarezal v rušo.

Zemlja se je nepretrgoma obračala.

$\mathrm{Na}$ ozarah je z enim samim trzljajem

Vajeti obrnil znojni par

In ga usmeril na njivo. $S$ strmim pogledom

Je premeril zemljo,

Natančno izmerjajoč brazde.
Jaz pa sem se spotikal po sledi njegovih okovanih čevljev,

Včasih padel na sveže zorano prst.

Včasih me je dvignil na hrbet,

Ki se je dvigal in spuščal nad njegovim napornim delom.

Želel sem si zrasti in orati,

Če zamižim na eno oko, učvrstiti roke.

Karkoli pa sem naredil, je bilo le sledenje

Njegovi široki senci okoli kmetije.

Bil sem stopicajoč, padajoč, vedno brbljajoč

Nadležnež. Toda danes

Je moj oče tisti, ki se kar naprej spotika

$\mathrm{Za}$ menoj in ne gre proč.

\section{Translated by Vera Pejović and Peter Semolič}

Considering Seamus Heaney's proverbial verbal minuteness, one is anything but surprised to come across such specialised technical terms from rural argot as "shafts", "wing", "sock", and "headrig". They are not problematic for a translator into the Slovene because of there would be a lack of equivalents in the target language but rather because all these words are more or less monosyllabic, whereas in Slovene the corresponding terms amount to two or even three syllables. With this in mind, I want to refer to Boris A. Novak, a co-translator of Heaney's poetry into the Slovene and the author of the essay in the book Močvirna dežela, who claims that English verses with exclusively monosyllabic words may in Slovene sound too harsh (Novak 1997, 72-3). Novak definitely has a point there; however, it has to be taken into account that Heaney, at the beginning of his poetic career, encouraged other 
Irish poets to roughen their poetic style. Therefore the enactment of the crudity of his style in the Slovene translation of Death of a Naturalist would only be a natural emulation of his poetic manifesto.

With regard to Heaney's extremely condensed, predominantly octosyllabic line, any Slovene translation, due to the inherent nature of the Slovene language, is doomed to not only violate the formal constraints of the original text, but also, and this is much more significant, blur the poet's following the traditional Irish seven-to-eight-syllable pattern. One should not overlook Heaney's art-long enterprise to achieve reconciliation between his Irish, intimately personal and nationalist affiliation, and the English literary and cultural traditions in which he was brought up. The poet elaborated on the amphibious nature of the writers like himself in his inaugural lecture The Redress of Poetry, delivered at Oxford University in 1989, when he became Oxford Professor of Poetry: "[All such writers] ... are caught on the forked stick of their love of the English language itself. Helplessly, they kiss the rod of the consciousness which subjugated them" (Heaney 1989, 9). Helplessly, indeed, yet at the same time, I dare say, helpfully, as confirmed in the opening of the poem 'Terminus':

Two buckets were easier carried than one.

I grew up in between.

Heaney's strongest weapon is sounded most loudly when he passes from the personal to the generic, from the parochial to the universal, which he achieves, somewhat paradoxically, by paying a tribute to the fundamentals of things. (In this respect Heaney seems to be governed by what his great master, Patrick Kavanagh, once said: "Parochialism is universal. It deals with the fundamentals.") As far as the formal properties of the poem are concerned, neither of the Slovene texts reveals adherence to the form or structure of the poem. The second translation (Pejović \& Semolič) is successful in providing comparatively exact designations for Heaney's ploughing terminology. However, its formal looseness fails to represent the author's striving to establish a link between the present and the past. The first translation (Novak \& Novak) is, admittedly, more compatible in terms of form, but it lacks the realisation of some crucial textual properties, for instance the so-called deibidhe practice - "the elegant, but initially very rough and un-English, rhyming of a monosyllable with a disyllable stressed on a syllable other than the rhyming one" (O’Donoghue 1994, 31) - such as "wing/breaking", "plough/furrow" - which again has a parallel in Yeats. Moreover, the translation does not pay adequate respect to the playfulness of Heaney's jargon, especially where he employs the many nautical allusions such as the father's shoulders which are like the billowing of a ship, the "sod" rolling over "without breaking" (like a wave), the child stumbling "in his wake", and "dipping and rising" on his father's back, and "[M] apping the furrow", the latter being a term used in navigating a ship. The intent of the speaker is not to show the farmer as simple but rather as one who is highly skilled, like one capable of navigating a ship. All these features no doubt aspire to raise the poem above the standards of typical rural poetry or the kind of poetry which is expressive of mere nostalgic feelings for lost childhood. 


\section{Watch-child of wells (Death of a Naturalist)}

The next poem, 'Personal Helicon', which happens to be the last poem in the same collection, presents Heaney in a slightly different light and at the same time paves the way for the subsequent book called $A$ Door into the Dark. Heaney, for that matter, has a curious habit of ending "one collection of his work with a piece which, in effect, will serve as a sort of 'manifesto' for the collection to follow" (Murphy 1996, 20). In the 'Personal Helicon' poem, which incidentally draws on the mountain and home of the Muses in Greece and location of the two springs which were believed by the Ancient Greeks to be the source of poetic inspiration, Heaney's commitment to his rural Irish ancestry tentatively gives way to a/the poet's vocation and the interplay between his public and private obligations. In this poem, Heaney the public man assumes the position of an adult, while his privacy is symbolised by the child-role and his prying into the local wells in search of knowledge. Heaney's pursuit of a dialogue between the two worlds of responsibility is reflected in the effective use of the so-called "mixed style", which in his case means a combined mobilisation of grown-up and infant linguistic behaviour.

\section{Personal Helicon}

for Michael Longley

As a child, they could not keep me from wells And old pumps and buckets and windlasses.

I loved the dark drop, the trapped sky, the smells

Of waterweed, fungus and dank moss.

One, in a brickyard, with a rotted board top.

I savoured the rich crash when a bucket

Plummeted down at the end of a rope.

So deep you saw no reflection in it.

A shallow one under a dry stone ditch

Fructified like an aquarium.

When you dragged out long roots from the soft mulch

A white face hovered over the bottom.

Others had echoes, gave back your own call

With a clean new music in it. And one

Was scaresome, for there, out of ferns and tall

Foxgloves, a rat slapped across my reflection.

Now, to pry into roots, to finger slime,

To stare, big-eyed Narcissus, into some spring

Is beneath all adult dignity. I rhyme

To see myself, to set the darkness echoing.

\section{Osebni Helikon}

\section{Za Michaela Langleyja}

Kot deček sem bil mahnjen na studence,

Starinske škripce, vedra iz vodnjaka,

Kjer je nebo ujeto, vlaga sence

Pa moči plesen in mehkobo maha.

V opekarni je imel vodnjak

Rjaveč pokrov. Poskusil sem bogat

Zven vedra, potopljenega v mrak,

Tako globok, da ne dogledaš dna.

Plitev izvir je izpod kamenite

Globeli obrodil kakor vsak akvarij.

Ko si iz glena spulil korenine,

Se je nad tlemi bel obraz pojavil.

Spet drugi so ti vračali odmev,

Ki je zvenel kot čista, nova glasba.

In bil je nek strašljiv vodnjak, poln praproti,

Kjer je čez moj odsev švistnila podgana.

A brskati po mulju, koreninah,

Strmeti kot Narcis v dno studenca,

Je pod odraslim dostojanstvom. Rimam,

Da vidim sebe, da odmeva senca.

\section{Translated by}

Boris A. Novak and Irena Zorko Novak 
Kot otroka me niso mogli spraviti proč od vodnjakov In starih črpalk z vedri in škripci.

Ljubil sem skrivnostna poklopna vrata, ujeto nebo, vonje po

Vodni travi, gobi in razmočenem mahu.

Eden, v opekarni, z nagnitim pokrovom.

Okusil sem slast močnega treska, ko je vedro

Na koncu vrvi navpično padlo.

Tako globoko, da nisi videl nobenega odseva v njem.
Drugi so odmevali, ti vračali tvoj lastni klic

$S$ čisto novo glasbo v njem. In eden

Je bil grozljiv, izmed praproti in dolgih

Naprstecev je podgana švignila čez moj odsev.

Zdaj je vtikanje nosu v korenine, bezanje po mulju,

Ogledovanje velikookega Narcisa v kakem tolmunu

Pod častjo odraslemu. Rimam,

Da vidim sebe, da sprožim temačno odmevanje.

Eden, plitev po izsušenim kamnitim koritom,

Je bil plodno polje kot vsak akvarij.

Ko si potegnil dolge korenine iz mehke zemlje,

Je bel obraz oblebdel nad dnom.

\section{Translated by Vera Pejović in Peter Semolič}

It is pretty obvious that the poet's standard concern with the relations between the Irish and English literary traditions has been withheld at this point. This is mainly indicated by his sparing use of alliteration (Heaney's habitual device, modelled upon the old Germanic rhetoric); instead, more emphasis is laid on the music of the vowels. Furthermore, the poem, which opens with "the kind of matter-of-fact tone", quickly shifts (in the third line) to the child's voice with a "succession of nouns and simple adjectives" (all quotes from Parker 1994, 75). The child's "over-personal" grammar - "[S]o deep you saw no reflection in it", "[W] hen you dragged out long roots", "[O]thers had echoes, gave back your own call" - is effectively recreated in both Slovene translations. However, the poem's final stanza, which "speaks of transition, triumph, the growth of a poet's mind" (idem), has been adequately rendered only in the Novak \& Novak translation. The same applies to the formulaic phrase "[I]s beneath all adult dignity", which happens to be "the schoolEnglish-lesson type of cliché known as 'command of English"” (O'Donoghue 1994, 41). The infinitival clauses "to pry into roots", "to finger slime" and "to stare...into some spring" are untypical of a child's speech both in English and Slovene, hence the Pejović \& Semolič translation, due to its gerundial rendition, falls short of a felicitous contrast. The very last sentence, "I rhyme/ To see myself, to set the darkness echoing" is of crucial importance here because, in support of Heaney's statement - "All I see is a door into the dark" - it sets the atmosphere of his next poetry collection, Door into the Dark. The Novak team has been most unfortunate at this point in translating "the darkness" as "senca" (BT: shadow), which is inconsistent with the title of the subsequent chapter in the book called Vrata $v$ temo (the translators' literal translation of Heaney's title). 


\section{Nothing quiet on the northern front}

'Punishment', first published separately as part of the Bog Poems (1975), but later included in the collection North (1975), is one of Heaney's persistently political poems, inspired by his reading of the book The Bog People: Iron Age Man Preserved, written by the Danish archaeologist P. V. Glob (1969). This particular poem, which "reports on the excavations of bodies of Iron Age people buried in bogs in north-western Europe, particularly in Denmark and Ireland ..., revived his own childhood images of bog land and it provided him with symbols and a mythical background enabling him to put the contemporary political scene in a wider historical and cultural perspective" (Verdonk 1993, 114¹).

\section{Punishment}

I can feel the tug of the halter at the nape of her neck, the wind on her naked front.

It blows her nipples to amber beads, it shakes the frail rigging of her ribs.

I can see her drowned body in the bog, the weighing stone, the floating rods and boughs.

Under which at first she was a barked sapling that is dug up oak-bone, brain-firkin:

her shaved head like a stubble of black corn, her blindfold a soiled bandage, her noose a ring

to store

the memories of love.

Little adulteress,

before they punished you

you were flaxen-haired, undernourished, and your tar-black face was beautiful. My poor scapegoat,

\section{Kazen}

Lahko začutim trzanje povodca na njenem tilniku in veter na njenem golem čelu.

Razpiha njene bradavice $\mathrm{v}$ jantarne jagode in stresa rahlo opravo na njenih rebrih.

Lahko vidim njeno potopljeno truplo v močvirju, obtežilni kamen, plavajoče protje in vejevje.

ki je pod njim najprej bila olupljena mladika, izkopana hrastova srž, posoda za možgane:

njena pobrita glava

kot strnišče črnega žita, trak čez oči umazana preveza, njena zanka prstan,

ki hrani

spomine na ljubezen.

Mala prešuštnica, preden so te kaznovali,

si bila podhranjena, lanenih las, in tvoj kot smola črn obraz je bil lep. Moj ubogi grešni kozel,

\section{Kazen}

Čutim teg vrvi na zadnjem delu njenega vratu, veter $\mathrm{v}$ njenih golih grudih.

Zburja bradavice $\mathrm{v}$ jantarjeve bisere, stresa krhki opaž iz njenih reber.

Vidim to telo, ki tone $\mathrm{v}$ šotno barje, mlinski kamen, plavne veje in protje.

Ki pod njim bila je sprva olupljena mladika, izkopana kot stržen, možganska srž:

njena obrita glava kot strnišče črne rži, preveza umazan trak, zanka prstan

v bran spomina na ljubezen. Mala prešuštnica, preden so te kaznovali

si bila lanenih las, podhranjena, tvoj smolnat črn obraz je bil prelep. Ubogi grešni kozel,

1 For a thorough and inspiring interpretation of this poem I recommend Peter Verdonk's study Poetry and public life: a contextualized reading of Seamus Heaney's 'Punishment' (in Verdonk 1993, 112 33). 
I almost love you

but would have cast, I know, the stones of silence.

I am the artful voyeur

of your brain's exposed and darkened combs, your muscles' webbing and all your numbered bones:

I who have stood dumb when your betraying sisters, cauled in tar, wept by the railings,

who would connive in civilized outrage yet understand the exact and tribal, intimate revenge. malone te ljubim, vendar bi tudi jaz, vem, vrgel kamenje tišine.

Jaz sem zvit voyeur

razkritih in potemnelih glavnikov tvojih možganov, tkanine tvojih mišic in vseh tvojih preštetih kosti:

jaz, ki sem nemo stal, ko so tvoje izdajalske sestre, povaljane v smoli, jokale ob ograji,

ki sem zmožen dajati potuho $s$ civiliziranim ogorčenjem, vendar razumem to natančno in plemensko, intimno maščevanje. in plemensko, intimno povračilo. skorajda te ljubim, a bi vrgel, vem, svoj kamen molka. Sem prekanjeni voyeur razkrinkanih stemnelih gub tvojih možganov, tvojih mišičnatih vlaken in preštetih ti kosti:

Jaz ki sem obstal molče, ko tvoje verolomne sestre so povaljane v katranu jokale ob ograji,

ki lahko delim civiliziran gnus, a razumem to eksaktno

Translated by Uroš Mozetič
Translated by Boris A. Novak and Irena Zorko Novak 
As observed by Peter Verdonk, the Nordic associations (like "amber beads", "barked sapling", "oak-bone", "brain-firkin", and "stubble of black corn") "are also accentuated by the poet's preference for vocabulary of Anglo-Saxon origin. Nearly all the concrete and earthly imagery is rooted in the Germanic core of the English language, while a minority of words stemming from its French or Latin influx such as "connive", "civilized", "exact", "intimate", "revenge", etc. are employed to refer to the abstractions related to the ambivalent attitude the poet takes in the last stanza" (Verdonk 1993, 128-9).

Furthermore, in this poem Heaney makes use of another stylistic device, kenning, a conventional metaphoric name for something, used especially in Old Norse and Old English poetry, here predominantly used with reference to the parts of the girl's body: "amber beads", "barked sapling", "oak-bone", "brain-firkin".

Every translator into Slovene, even if aware of such lexical discrimination, is in a serious quandary here. The option to rely on such international foreign words as konivenca for "connivance", civiliziran for "civilized", eksakten for "exact", intimen for "intimate", and revanša for "revenge" is, poetically speaking, for the most part not a very good solution. Alternatively, drawing on the former Yugoslav oppressor's, i.e. Serbian lexicon, because the lexical shift in the Heaney text may have been prompted by the desire to strike a contrast between the Norman and Anglo-Saxon linguistic control, and hence creating something like:

$\cdots$

koji bi povlađivao

u civilizovanom pogrdu

a shvatio tačno određenu

i plemensku, prisnu osvetu ${ }^{2}$

is tempting but runs the risk of sounding politically incorrect, if not provocative. So what we are left with (except for the collocation "civiliziranim ogorčenjem" in the final stanza) is a politically, historically and linguistically unmarked Slovene translation of the poem which depends for its vitality on the essentially politically, historically and linguistically marked expression.

\section{New vistas}

A radically different type of poetic vision and experience is presented in the collection Seeing Things, published in 1991. I have chosen an excerpt from the title poem to point out some of Heaney's linguistic and stylistic devices, not entirely new but this time employed with a slightly different and often amazingly elegant turn. This collection proves that Heaney's poetry is indeed "an art that knows its mind", as he himself once referred to it. Bernard O'Donoghue contends that "[S]eeing Things sets itself an extremely ambitious programme of mediations: between this world and the next, between youth and age, between the

2 The Serbian translation of this text was provided by Milan Semen, a fourth-year student of English at our Department. 
terrestrial and extra-terrestrial" (O'Donoghue 1994, 119-20), for the purpose of which he introduces certain rhetorical and grammatical procedures to promptly articulate his central notion of "unsayability". (The very notion is embedded already in the title, implying simultaneously two mutually exclusive human faculties: that of getting to the root of the matter and that of mere imagination/hallucination.) If in his previous collections Heaney has been reasonably confident of his choice of words and their combinations, he now seems to be somewhat at a loss for the "right" expression. The reason, of course, is not to be sought in the limitations of the author's own poetic eloquence, but rather in the nature of the world(s) he is describing. Physical and spiritual transience, the complex relationship between the marvellous and the actual, between the material and the transcendental are not easily put into words. In addition to that, this is also the period of Heaney's struggling to come to terms with the death of both his parents (mother 1984, father 1986). So how does the poet's condition as well as his search for the security of a new meaning manifest itself in the linguistic-stylistic apparatus of these poems?

\section{Seeing Things}

I.

Inishbofin on a Sunday morning.

Sunlight, turfsmoke, seagulls, boatslip, diesel.

One by one we were being handed down

Into a boat that dipped and shilly-shallied

Scaresomely every time. We sat tight

On short cross-benches, in nervous twos and threes,

Obedient, newly close, nobody speaking

Except the boatman, as the gunwales sank

And seemed they might ship water any minute.

The sea was very calm but even so,

When the engine kicked and our ferryman

Swayed for balance, reaching for the tiller,

I panicked at the shiftiness and heft

Of the craft itself. What guaranteed us-

That quick response and buoyancy and swim-

Kept me in agony. All the time

As we went sailing evenly across

The deep, still, seeable-down-into water,

It was as if I looked from another boat

Sailing through air, far up, and could see

How riskily we fared into the morning,

And loved in vain our bare, bowed, numbered heads.

\section{Videnje stvari}

I.

Inishbofin v nedeljskem jutru.

Sonce, šotni dim, galebi, drsenje ladij, diesel.

Drugega za drugim so nas posajali

$\mathrm{v}$ čoln, ki se je omahovaje vsakokrat

preplašeno ugrezal. Sedeli smo otrplo

na prečnih klopeh, nervozne dvojice, trojice,

poslušni, prvič skupaj, molčeči vsi

razen čolnarjev, ko so boki tonili

In se je zdelo, da bodo vsak hip zajeli vodo.

Morje je bilo zelo spokojno, pa vendar me je,

ko je stroj sunil in se je naš krmar,

loveč ravnotežje, zazibal in segel po krmilu, napolnjevala s strahom nezanesljivost in teža same ladje. Kar nam je jamčilo-

tisti nagel odziv in vzgon in plovnost-

me je mučilo. Ves čas

naše gladke plovbe nad globoko,

mirno, daleč navzdol vidno vodo je bilo,

kot da gledam iz nekega drugega čolna,

ki plove skozi zrak, visoko zgoraj, in vidim,

kako tvegano potujemo skoz jutro

in zaman ljubim naše gole, sklonjene, štete glave.

\section{Translated by Veno Taufer (1995)}

In the first place, we can observe a "progressive reducing of activeness in verbs" and Heaney's much-cherished tendency "to form verbs from nouns by simple conversion without inflection: the process called 'zero derivation”" (O’Donoghue 1994, 130). The second line, however, strikes 
a note of imitating the Yeatsian list of trochees: "Sunlight, turfsmoke, seagulls, boatslip, diesel", as possibly an embodiment of "the idea of steadying as a 'guarantee' in the face of transience" (ibid., 133). Needless to say, the metric looseness of the translation fails to represent this idea. Third, the employment of the so-called "negativing prefixes"3 elsewhere in the collection such as "undrowned", "undead", "unfurtive" reminds us of the liminal (relating to the point or threshold beyond which a sensation becomes too faint to be experienced) essence of language, and its function as mediator. Fourth, Heaney's introduction of and variations on compound lexical items such as "seeable-down-into-water", to a large extent lost on the Slovene translation, may be understood as a deficiency of language "to express what is required" (idem). The very last collocation in the poem, "numbered heads", an allusion to the Psalms (22:16-17) ...they pierced my hands and my feet. I may tell all my bones: they look and stare upon me" establishes the poem's link with the ultimate salvation. The grammatical mistranslation of the word "numbered" as "stete", which is as an inchoate adjective, rather than "prestete", may not, God willing, prevent the Slovene reader from "seeing things".

\section{Heritage and homage}

Every poem has its textual as well as intertextual habitation. To this end, my final case, an excerpt from the poem 'On His Work in the English Tongue', draws on Heaney's latest poetry collection, Electric Light (2001). This volume possesses many of the usual themes and styles, which altogether betrays an unmistakable stroke of Heaney's and can be summed up as "the appreciation of word and phrase, the love for the pastoral, for mythic and natural presence, for the quotidian, and for the political significance of border and tribe" (Holdridge 2001). The book, in the poet's own words, is divided "into a section of the rather more elegiac poems, with all the other poems in a separate section" (Heaney 2001, 25). The "elegiac" section comprises poems written for recently deceased friends, among them Heaney's fellow poets Ted Hughes, Joseph Brodsky and Zbigniew Herbert. These are poems that "might seem to call into question the pertinence of 'the ground of your own understanding' in the face of mortality and impermanence" (O'Grady 2001). Heaney's preoccupation with the death of his peers in this volume is further upheld in the interview on the occasion of his visit to Portugal in May 2001, to participate in the colloquium Identities: a European Poets' Meeting, where he says: "I have a couple of subjects, but they are more or less political subjects, and I think that the political moment, the political urgency is past for me. This is more the moment of mortality ..." (Heaney 2001, 26).

In order to duly commemorate the life and work of his fellow-poets, Heaney resorts to the means which seem to be fairly appropriate to the case in point - meta-language and intertextuality. The ultimate effectiveness is, consequently, arrived at through the simulation of the form and the poetry-binding spirit like in his 'Audenesque' poem, written in the memory of Joseph Brodsky : "Joseph, yes, you know the beat./ Wystan Auden's metric feet/ Marched

3 Curiously, and perhaps inappropriately in the light of the occassion, Heaney employed this rhetorical device in his recent poetry-address to the newly accessed states to the European Union, which took place in Phoenix Park in Dublin, 1 May 2004: "... So on a day when newcomers appear/ Let it be a homecoming and let us speak/ The unstrange word, as it behoves us here, ..." (my emphasis). 
to it, unstressed and stressed,/ Laying William Yeats to rest." The poem, which adopts the same stanza and metric form as the third and last part of Auden's elegy 'In Memory of W. B. Yeats', alludes to Brodsky's life-long fascination with Auden, at the same time evoking and confirming Yeats' spectrum of "each age /unwinding/ the thread another age had wound ...all things dying each other's life, living each other's death" (Yeats 1925, 183). Alternatively, Heaney connects himself to the common poetic heritage by means of employing necessary lexical-phonetic properties such as wordplay, his sometimes painfully popular device, at least from the translator's point of view, as illustrated below with an excerpt from the poem 'On His Work in the English tongue':

\section{On His Work in the English Tongue}

in memory of Ted Hughes

1

Post-this, post-that, post-the-other, yet in the end Not past a thing. Not understanding, or telling Or forgiveness.

But often past oneself,

Pounded like a shore by the roller griefs

In language that can still knock language sideways.

\section{O njegovem delu v angleškem jeziku}

v spomin Tedu Hughesu

\author{
Posto-to, post-tisto, post-ostalo, na koncu pa \\ postaja ista. Mimo ne uvida ne povedi \\ ne odpuščanja. \\ A pogosto mimo sebe, \\ stolčen kot obala od valovja bolečine \\ v jeziku, ki še vedno zna zadeti jezik z boka.
}

Soul has its scruples. Things not to be said.

Things for keeping, that can keep the small-hours gaze Open and steady. Things for the aye of God

And for poetry. Which is, as Miłosz says,

'A dividend from ourselves,' a tribute paid

By what we have been true to. A thing allowed.
Duša ima svoje zadržke. Stvari, ki jih ne gre izreči.

Stvari, ki se jih zadrži, ki zadržijo zrenje $\mathrm{v}$ ranih urah neprikrito in na preži. Stvari za O.K.(o) Boga in poezijo. Kar je, kot bi rekel Miłosz, 'dividenda od nas samih', davek, ki smo ga plačali $s$ tem, da smo ostali zvesti. Dopustna stvar.

\section{Translated by Uroš Mozetič}

Here the lexical-phonetic pun "post-past", which purports to designate Ted Hughes' progression from one poetic state to another, is tied with the poet's essentially humanist position: Not past "understanding,/ or telling/ Or forgiveness". There are, naturally, a variety of reasons preventing the Slovene translator from faithfully recreating the pun-chain, however, a sort of compensation may still be arrived at. To that effect, I have chosen to make use of the phonological/lexical wordplay in Slovene: post/postaja. The latter word, in back translation, felicitously corresponds to the word station, which alludes to Heaney's poetry collection Station Island (1984). This collection namely "takes its basic conceit from the tradition of pilgrimage literature" (Murphy 1996, 60), ... [W] ith its stress on the bond between the living and the dead, its emphasis on the path of renunciation and sacrifice ..." (Parker 1994, 182). There is a very short step 
from here to Ted Hughes, for I do not believe that Heaney is after some simple, traditional elegy, which would tell us about the deceased one what we always knew but were not sure of. Rather, we are confronted with an unprecedented reforming of a tombstone scripture which the R.I.P.-resident might be reluctant to solicit for, notwithstanding the kindness and respect from the fellow-poet and colleague. A great poet, when he dies, according to Auden, turns into his own work, becomes an object of admiration. The poet's life thus falls into oblivion, not because it would be of no significance but because, as far as his readers are concerned, there is no life at stake any more. And this is where Heaney comes in. He wants to present us with a poet in flesh, for better or worse, a man like any one of us, full of contradictions within as well as without, someone who was all his life torn between his body and soul (incidentally the title of another Heaney poem), but nevertheless or rather because of it managed to preserve the ability to indulge in "passive suffering".

In the last section of the poem Heaney brings the poem to its climax by means of referring to his Polish master Czesław Miłosz. On this account he produces a triple word-play cluster: "Things for keeping, that can keep.../ Things for the aye of God .../a tribute paid by what we have been true to" (my emphasis). In the first part, the play on words is enacted by the different semantic figuration of the verb "keep"; in the second instance, the play is substantiated by the archaic or Scottish dialectal "aye", meaning "yes", that is approval; and last, the "tribute" may be a gift or statement made in acknowledgement, gratitude or admiration, or (in feudal society) a payment rendered by a vassal to his lord. Since the Slovene term "tribut" renders only 'levying taxes' by a feudal lord, I have chosen to replace the original "tribute" by the Slovene word "davek" ("tax"), so as to stress the poets' sacrificial commitment to their common guilt.

\section{Conclusion}

These are only some of the problems of translating the poetry of Seamus Heaney into Slovene or, put more daringly, of translating Seamus Heaney language-wise. Presumably, one does not need to have a command of all the languages of the world to sense the essential untranslatability of Heaney's poetic voice. Understanding and rendering his poetry depends for its effect on the reader's ability to perceive the origins of the Irish-English political, historic, and cultural confrontation, which manifest themselves in the specific designation of the choice of Heaney's utterance. Therefore, our assumption is that a comparatively accurate translation of Heaney's poetry would be feasible only if a target language had been, in the history of its development, to some extent exposed to a socio-linguistic trial similar to that of the Irish. However, this is merely a precondition for coming to terms with the complexity of the author's expression. What is almost equally required between the two parties is a certain felicity of linguistic proximity. And here the Slovene language lies fallow. In terms of political and cultural history, the Slovene people may indeed have much in common with the Irish, but in terms of language there appears to be a set of insurmountable difficulties. Being a member of the Slavic family, the Slovene language possesses certain natural traits inherently different from those of the Irish-English vernacular. In addition to those that have been dealt with in this paper, there 
are some other unequivocal issues which will have to be tackled in the on-going discussion of the status of Heaney's poetry in a foreign-language code: in particular, the poet's arbitrary employment of word-formation rhetoric as part of his poetic style; his use of the nationalist and individual-specific vocabulary; and the significance of his vocation for the promotion of other poetic manifestations, either within the context of their own cultural traditions or with reference to their role in the cultural environment of the expanding European Union. The latter, especially, seems to be bound to exercise a decisive effect on the common prosperity of the newly gathered nations.

\section{Bibliography}

Bőll, H. 1995. Irski dnevnik. Prev. V. Klabus. Zbirka S poti. Ljubljana: Cankarjeva založba.

Heaney, S. 1989. The Redress of Poetry. An Inaugural Lecture delivered before the University of Oxford on 24 October 1989. Oxford: Clarendon Press.

- - - 1998. Opened Ground. Poems 1966 - 1996. London: Faber and Faber.

- - -. 2001. Electric Light. London: Faber and Faber.

- - - 2001. On Elegies, Eclogues, Translations, Transfusions: an interview with Seamus Heaney (R.C. Homem). The European English Messenger X/2: 24-30.

- - - 2004. Beacons at Bealtaine (Phoenix Park, May Day, 2004). http://www.drrnwbb.com/blog/ (accessed 10 May 2004 )

Holdridge, J. 2001. Electric Light - By Seamus Heaney. Sunday Business Post, August 22. http://archives.tcm.ie/ businesspost/2001/08/22/story303870.asp (accessed 23 April 2004)

Murphy, A. 1996. Seamus Heaney. Writers and Their Work. Plymouth, U.K.: Northcote House.

Novak, B.A., and I.Z. Novak, trans. 1997. Močvirna dežela. Radovljica: Didakta.

Novak, B.A. 1997. Seamus Heaney, pesnik osebnega in kolektivnega spomina. In Novak and Novak, 69-73.

O'Donoghue, B. 1994. Seamus Heaney and the Language of Poetry. Hemel Hempstead: Harvester Wheatsheaf.

0'Grady, T. 2001. Into, Out of Heaney's Known World. [Originally published, in a slightly different form, in The Boston Sunday Globe, May 27, 2001] http://omega.cc.umb.edu/ irish/electric light.htm (accessed 9 January 2003)

Parker, M. 1994. Seamus Heaney. The Making of the Poet. Houndmills, Basingstoke, Hampshire, and London: Macmillan.

Pejović, V., and P. Semolič, trans. 1992. Seamus Heaney: pesmi. Razgledi, 10. januarja, 29.

Taufer, V., trans. 1995. Letošnji dobitnik Nobelove nagrade za književnost. Delo (Književni listi), 19. oktobra, 16.

Verdonk, P., ed. 1993. Twentieth-Century Poetry. From Text to Context. Interface. London and New York: Routledge.

Trstenjak, A. 1992. Misli o slovenskem človeku. Ljubljana: Založba Mihelač.

Yeats, W.B. 1956. A Vision. New York: Macmillan. 